\title{
Komoditas Perkebunan Unggulan yang Berbasis Pada Pengembangan Wilayah Kecamatan di Kabupaten Banjarnegara Provinsi Jawa Tengah
}

\author{
Pawit Setianto ${ }^{1}$ \\ Dinas Kehutanan dan Perkebunan, Pemerintah Kabupaten Banjarnegara
}

\author{
Indah Susilowati² \\ Program Studi Magister Pembangunan Wilayah dan Kota \\ Universitas Diponegoro, Semarang
}

Artikel Masuk : 21 Juni 2014

Artikel Diterima : 31 Juli 2014

\begin{abstract}
Abstrak: Perencanaan pembangunan berdasarkan perwilayahan komoditas dapat mengatasi persaingan jenis komoditas antar wilayah. Identifikasi dan analisa potensi wilayah perlu dilakukan dalam rangka pengembangan ekonomi wilayah yang merupakan informasi awal dalam merumuskan atau mempersiapkan strategi pengembangan potensi yang ada. Tujuan dari penelitian ini adalah untuk memetakan, menganalisis dan memberikan arahan dalam pengembangan komoditas perkebunan unggulan pada masing-masing kecamatan. Metode yang digunakan diskriptif statistik dengan melakukan overlay terhadap peta-peta iklim, curah hujan, suhu dan topografi. Analisis yang dipakai adalah analisis kesesuaian lahan, Location Quotient (LQ), Shift Share dan Delphi. Komoditas unggulan perkebunan yang mempunyai prioritas tinggi untuk dikembangkan di Kabupaten Banjarnegara adalah berturut-turut kelapa deres, teh, kopi robusta, kopi arabika, kelapa dalam, karet, dan tebu. Wilayah potensial untuk pengembangan tanaman kelapa dalam adalah Kecamatan Mandiraja dan Susukan. Sedangkan wilayah potensial untuk pengembangan tanaman kelapa deres adalah Kecamatan Bawang, Purwonegoro, Rakit, Susukan dan Wanadadi. Kopi arabika potensial di Kecamatan Pejawaran dan Pagentan. Pengembangan tanaman kopi robusta adalah Kecamatan Banjarnegara, Wanadadi dan Punggelan. Wilayah pengembangan teh adalah Kecamatan Pagentan, dan Wanayasa. Karet bisa dikembangkan di Kecamatan Punggelan, Purwonegoro, Susukan, Rakit, Mandiraja, Purworejo Klampok dan Wanadadi. Tebu dapat dikembangkan di Kecamatan Bawang, Purwonegoro, Susukan, Mandiraja, Rakit dan Wanadadi.
\end{abstract}

Kata Kunci: Banjarnegara, Potensi, Perkebunan, Unggulan, Pengembangan Wilayah, Perwilayahan Komoditas

\begin{abstract}
Development planning based on comodities zoning can overcome competition commodities between regions. Identification and analysis of potential areas needs to be done in the framework of economic development of the region that can be used as first information for formulation and preparing strategies to develop the existing potential. The purpose of this study is to map, analyze and provide guidance for the development of leading plantation commodities in each district. The method of this study is statistics descriptive by overlaying
\end{abstract}

\footnotetext{
${ }^{1}$ Korespondensi Penulis: Dinas Kehutanan dan Perkebunan, Pemerintah Kabupaten Banjarnegara Email: pawitsetianto@yahoo.co.id

2 Email: indahsusilowati@ rocketmail.id
} 


\section{Komoditas Perkebunan Unggulan yang Berbasis Pada Pengembangan Wilayah Kecamatan...}

the maps of climate, rainfall, temperature and topography. The analysis types of this study are land suitability analysis, Location Quotient (LQ), shift share and Delphi. Leading plantations commodities that have high priority to be developed in District Banjarnegara are coconut sugar, tea, robusta coffee, arabica coffee, coconut, rubber, and cane. Potential areas for development of coconut plants are Sub-District Mandiraja and Susukan. While the potential areas for development of coconut sugar is Sub-District Bawang, Purwonegoro, Rakit, Wanadadi and Susukan. Arabica coffee is potential in Sub-District Pejawaran and Pagentan. Robusta coffee plant development is in Sub-District Banjarnegara, Wanadadi and Punggelan. Tea plants development area is Sub-District Pagentan and Wanayasa. Rubber can be developed in the Sub-District Punggelan, Purwonegoro, Susukan, Rakit, Mandiraja, Purworejo Klampok and Wanadadi. Cane can be developed in Sub-District Bawang, Purwonegoro, Susukan, Mandiraja, Rakit and Wanadadi.

Keywords: Banjarnegara, Potential, Plantation, Leading, Regional Development

\section{Pendahuluan}

Pendekatan pembangunan wilayah dapat dilakukan berdasarkan potensinya. Kebijakan pembangunan terkait dengan pengembangan wilayah tidak dapat dilihat secara umum tanpa melihat potensi keragaman komoditas, namun harus spesifik wilayah supaya program tersebut dapat dilaksanakan dengan baik, tepat sasaran dan nyata.

Kabupaten Banjarnegara secara umum merupakan wilayah yang terletak pada kawasan dengan potensi iklim dan kondisi lahan yang beragam karakteristiknya. Adanya keragaman sifat fisik lahan ini dapat dijadikan modal dasar yang dapat di pakai dalam melakukan pertimbangan dalam menentukan perwilayahan komoditas pertanian. Keragaman sifat fisik lahan akan menentukan jenis komoditas yang dapat diusahakan serta akan berpengaruh terhadap tingkat produktifitasnya. Perencanaan pembangunan pertanian yang berdasarkan perwilayahan akan dapat mengatasi terjadinya persaingan jenis antar wilayah.

Subsektor perkebunan sebagai bagian dari sektor pertanian dapat berperan aktif dalam rangka peningkatan perekonomian wilayah. Untuk lebih meningkatkan kemakmuran yang lebih seimbang dan merata antar daerah diperlukan perencanaan pembangunan dengan kebijakan-kebijakan yang dapat merangsang perkembangan wilayah sesuai dengan potensinya masing-masing, tetapi masih dalam pengendalian dan arahan pemerintah.

Perencanaan pembangunan dimulai dengan menganalisis kondisi wilayah, potensi unggulan wilayah dan permasalahan yang ada di wilayah tersebut yang selanjutnya dapat digunakan sebagai dasar pertimbangan dalam menentukan strategi pengembangan wilayah. Perencanaan pembangunan yang baik sangat diperlukan ketersediaan informasi dan data tentang potensi sumber daya alam dan persebarannya sehingga dapat mendukung perencanaan pembangunan daerah termasuk pembangunan perkebunan.

Perencanaan pengembangan wilayah yang berbasis pada potensi komoditas perkebunan unggulan perlu diketahui melalui pemetaan potensinya. Berkaitan dengan hal tersebut perlu dilakukan sebuah pemetaan dan kajian arahan perencanaan pembangunan berbasis perwilayahan komoditas perkebunan di Kabupaten Banjarnegara. Berangkat dari perwilayahan komoditas unggulan, maka diperlukan analisis mengenai pemetaan potensi suatu wilayah terhadap komoditas perkebunan unggulan yang terdapat pada masingmasing kecamatan di Kabupaten Banjarnegara.

Tujuan umum dari penelitian ini adalah untuk memetakan, menganalisis dan memberikan arahan pengembangan komoditas perkebunan unggulan pada masing-masing kecamatan untuk mendukung strategi kebijakan pembangunan pertanian di Kabupaten Banjarnegara. 


\section{Metode Penelitian}

Metode penelitian dilakukan dengan teknik observasi (kunjungan) dan wawancara/kuisioner. Teknik analisis yang digunakan dalam penyusunan kesesuaian lahan suatu komoditas adalah dengan melakukan overlay terhadap peta-peta iklim, curah hujan, suhu dan topografi dengan memperhatikan syarat tumbuh tanaman dan arahan fungsi lahan. Hasil proses penilaian kesesuaian lahan diwujudkan dalam bentuk sistem klasifikasi kesesuaian lahan dengan hirarki kelas-kelas kesesuaian lahan adalah kelas sangat sesuai (S1), kelas cukup sesuai (S2), kelas sesuai marjinal (S3), dan kelas tidak sesuai (N) (Baja, 2012).

Komoditas menggunakan metode Location Quotient (LQ). Apabila memiliki nilai LQ $>1$ dapat dikatakan bahwa komoditas perkebunan tersebut merupakan komoditas basis atau unggulan.

Arahan perwilayahan komoditas perkebunan unggulan yang akan ditetapkan memperhatikan analisis sebagai berikut:

a. Analisis komoditas basis / unggulan wilayah kabupaten dan kecamatan berdasarkan analisis Location Quotient (LQ) luas lahan.

b. Analisis penentuan komoditas unggulan dari pemegang kebijakan.

c. Analisis kesesuaian lahan, yang menghasilkan kelas kesesuaian lahan bagi komoditas pertanian tertentu pada suatu lokasi.

d. Analisis komoditas unggulan yang menghasilkan komoditas unggulan perkebunan basis dan non basis di suatu kecamatan.

e. Analisis daya saing atau pertumbuhan pangsa wilayah komoditas di wilayah kecamatan.

Untuk mengidentifikasi pertumbuhan wilayah atau sektor dalam suatu daerah menggunakan analisis pertumbuhan wilayah (Shift dan Share). Selanjutnya dilakukan Analisis Gabungan (Superimpose) dari hasil-hasil analisis LQ, pertumbuhan regional, pertumbuhan proporsional, pertumbuhan pangsa wilayah dan analisis komoditas unggulan dengan metode Delphi di gabung untuk mengetahui keunggulan dari komoditas yang sedang dianalisis. Komoditas yang sangat unggul akan memiliki nilai gabungan yang paling tinggi.

Pada penelitian ini, komoditas yang dikembangkan di setiap wilayah kecamatan adalah komoditas yang merupakan komoditas unggulan dan potensial. Dikatakan unggulan apabila di suatu wilayah kecamatan memiliki keunggulan kompetitif dan komparatif, sedangkan dikatakan komoditas potensial apabila memiliki kompetitif atau komparatif saja.

\section{Tinjauan Pustaka}

Perwilayahan komoditas mempunyai peranan sangat penting dalam mengarahkan pola sebaran pengembangan komoditas yang mengacu pada agroekologi, sehingga diharapkan dapat lebih mengoptimalkan penggunaan lahan dan peningkatan produksi pertanian. Pemetaan komoditas perkebunan unggulan yang berbasis pada pengembangan wilayah kecamatan ini akan memberikan gambaran kawasan mana yang akan dikembangkan dan jenis tanamannya sehingga keterkaitan secara ekonomis dengan kawasan pengembangan lebih jelas dan terarah. Menurut Suparmoko (2001), bahwa identifikasi dan analisa potensi wilayah yang perlu dilakukan dalam rangka pengembangan ekonomi wilayah merupakan informsi awal dalam merumuskan atau mempersiapkan strategi pengembangan potensi yang ada. Untuk itu langkah-langkah yang perlu ditempuh 


\section{Komoditas Perkebunan Unggulan yang Berbasis Pada Pengembangan Wilayah Kecamatan.. .}

adalah (1) mengidentifikasi sektor-sektor kegiatan mana yang mempunyai potensi untuk dikembangkan dengan memperhatikan kekuatan dan kelemahan masing-masing sektor; (2) mengidentifikasi sektor-sektor yang potensinya rendah untuk dikembangkan, dan mencari faktor-faktor yang menyebabkan rendahnya potensi sektor tersebut untuk dikembangkan; (3) mengidentifikasi sumber daya (faktor produksi) yang ada, termasuk sumberdaya manusianya dan yang siap digunakan untuk mendukung perrkembangan setiap sektor yang bersangkutan; (4) dengan melakukan pembobotan terhadap variabel-variabel kekuatan dan kelemahan untuk setiap sektor dan subsektor, maka akan ditemukan sektor-sektor andalan yang selanjutnya dianggap sebagai potensi ekonomi yang patut dikembangkan di daerah yang bersangkutan dan (5) menentukan strategi yang akan ditempuh untuk pengembangan sektor-sektor andalan yang akan dapat menarik sektor-sektor lain untuk tumbuh sehingga perekonomian akan dapat berkembang dengan sendirinya secara berkelanjutan (sustainable development).

Identifikasi komoditas tanaman perkebunan unggulan yang potensial untuk dapat dikembangkan di masing-masing kecamatan di Kabupaten Banjarnegara pada penelitian ini didasarkan pada komoditas yang memiliki keunggulan kompetitif dan keunggulan komparatif, atau memiliki keunggulan kompetitif atau komparatif saja. Keunggulan kompetitif adalah apabila komoditas tersebut mampu bersaing dengan komoditas yang sama dengan daerah lain, hal ini dapat diukur dengan melihat komponen Cij (komponen keunggulan kompetitif) pada analisis Shift Share. Jika nilai Cij pada analisis Shift Share bernilai positif, maka komoditas tersebut memiliki keunggulan kompetitif.

Ada beberapa alat analisis yang dapat digunakan untuk menentukan potensi relatif perekonomian suatu wilayah. Alat analisa itu antara lain keunggulan komparatif, location quotient dan analisis shif-share (Tarigan, 2005).

Menurut Herdhiansyah dkk (2012) analisis data yang digunakan dalam identifikasi perkebunan komoditas unggulan menggunakan Metode Delphi dan diskriptif kualitatif. Analisis Location Quotient (LQ) untuk menggambarkan keberadaan sektor basis yang selanjutnya digunakan sebagai sektor unggulan (Rustiadi, dkk, 2011). Menurut Hendayana (2003), dalam mengaplikasikan metode LQ untuk tanaman digunakan satuan luas areal panen.

Selain itu suatu komoditas juga dapat dikatakan memiliki keunggulan komparatif apabila hasil produksi suatu komoditas di sauatu wilayah hasilnya dapat memenuhi kebutuhan dalam daerahnya dan sisanya masih bisa diekspor keluar. Hal ini bisa dilihat dengan menggunakan metode Location Quotient (LQ) yaitu membandingkan luas panen tanaman perkebunan di setiap kecamatan dengan luas panen tanaman perkebunan kabupaten. Apabila nilai analisis Location Quotient (LQ) pada suatu komoditas suatu wilayah bernilai lebih besar dari satu (LQ > 1) maka dapat dikatakan bahwa komoditas tersebut memiliki keunggulan komparatif.

$$
L Q=\frac{S i / N i}{S / N}=\frac{S i / S}{N i / N} \quad \begin{array}{ll}
\mathrm{LQ} & =\text { Besarnya koefisien lokasi komoditas perkebunan } \\
\mathrm{Si} & =\text { Besarnya koefisien lokasi komoditas perkebunan } \\
\mathrm{S} & =\text { Jumlah (total luas panen ) pangan tingkat kecamatan } \\
\mathrm{Ni} & =\text { Jumlah luas panen komoditas i pada tingkat kab. } \\
\mathrm{N} & =\text { Jumlah total luas panen komoditas tingkat kab. }
\end{array}
$$

\section{Hasil dan Pembahasan}

Hasil analisis pertumbuhan regional tanaman perkebunan periode 2008 - 2012 di Kabupaten Banjarnegara menunjukkan bahwa tanaman perkebunan mengalami peningkatan. Hal ini tercermin pada koefisien pertumbuhan regional bernilai positif yaitu 
sebesar 0,023. Penyebab utama peningkatan tersebut adalah adanya kegiatan yang dilakukan pemerintah daerah dalam optimalisasi dan perluasan areal lahan perkebunan.

\section{Kelapa}

Tanaman kelapa yang terdapat di Kabupaten Banjarnegara terdiri dari kelapa deres dan kelapa dalam. Berdasarkan analisis Delphi, yang diperoleh dari pendapat pemangku kebijakan perkebunan atas potensi komoditas, kelapa deres mempunyai rata-rata paling tinggi terhadap potensi kelapa deres yang dilakukan dikarenakan komoditas tersebut masih tersedia potensi lahan untuk pengembangan yang sangat luas, harga jual produksi yang baik dan dapat memberikan keuntungan (nilai ekonomi tinggi) dan tersedianya dukungan teknologi dalam budidaya dan penanganan pasca panen.

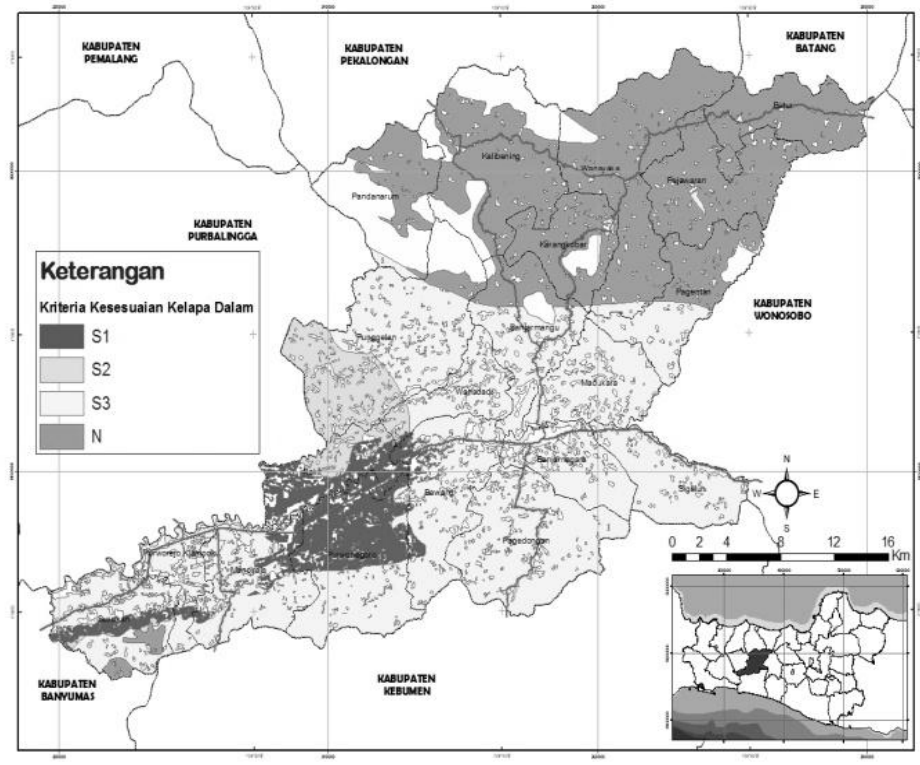

\section{Gambar 1. Peta Kesesuaian Lahan Tanaman Kelapa di Kabupaten Banjarnegara}

Berdasarkan analisis kesesuaian lahan, bahwa potensi kesesuaian lahan (S) untuk kelapa yang cukup tinggi yaitu mencapai $61.711,69 \mathrm{Ha}$. Adapun kelas lahan yang sangat sesuai (S1) banyak terdapat di Kecamatan Purwonegoro, Rakit, Susukan, Mandiraja, Bawang, Purworejo Klampok, Wanadadi dan Punggelan. Berdasarkan data tahun 2012 saat ini luas kelapa deres saat ini $1.431,18 \mathrm{Ha}$ dengan jumlah produksi $10.273,31$ ton gula kelapa, yang paling banyak berada di Kecamatan Susukan, Mandiraja dan Purwonegoro.

Pada tingkat wilayah, berdasarkan hasil analisis Location Quotient (LQ) terhadap komoditas tanaman perkebunan didapatkan wilayah yang memiliki LQ $>1$ (basis) kelapa dalam terdapat di Kecamatan Purwonegoro, Madukara, Sigaluh, Pagedongan, Susukan, Wanadadi, Mandiraja, Bawang, Banjarmangu, Purwareja Klampok, Banjarnegara dan Rakit. Sedangkan kelapa deres di deretan selatan barat yaitu di Kecamatan Purwareja Klampok, Susukan, Mandiraja dan Purwonegoro. Berdasarkan analisis pertumbuhan pangsa wilayah, daerah yang memiliki daya saing untuk tanaman kelapa dalam dan kelapa deres untuk tanaman Kecamatan Susukan, Bawang, Banjarnegara, Pagedongan, Rakit dan Punggelan.

Arahan perwilayahan komoditas kelapa dalam dan paling potensial untuk pengembangan adalah Kecamatan Mandiraja dan Susukan. Kecamatan Bawang dan Rakit juga mempunyai potensi walaupun bukan wilayah basis kelapa, tetapi pertumbuhan pangsa wilayah bernilai positif. Sementara itu kecamatan basis yang cukup potensial adalah 
Kecamatan Purwonegoro dan Purworejo Klampok, walaupun pertumbuhan pangsa wilayah negatif. Hal ini dikarenakan banyaknya tanaman yang sudah tua dan ditebang untuk digunakan sebagai kayu bangunan. Sementara itu tidak diimbangi dengan penanaman tanaman baru. Faktor serangan hama juga ikut memicu tanaman lebih cepat ditebang. Tanaman kelapa dalam dipanen dalam bentuk buah kelapa sebagai kelapa sayur maupun sebagai kelapa muda.

Wilayah pengembangan tanaman kelapa merupakan wilayah fungsional dataran rendah yang menjadi satu kesatuan yaitu di Kabupaten Banjarnegara bagian selatan melintang dari barat sampai timur. Sementara untuk kondisi pertanaman terdapat di tanah kering non irigasi dan merupakan tanaman tumpang sari dengan tanaman lain seperti tanaman buah, tanaman sayuran dan tanaman ubikayu. Sedangkan kecamatan yang paling potensial untuk pengembangan tanaman kelapa deres adalah Kecamatan Bawang, Purwonegoro, Rakit, susukan dan Wanadadi. Kecamatan Banjarmangu, Banjarnegara, Madukara, Pagedongan, mempunyai potensi dikarenakan merupakan daerah basis, walaupun mempunyai kelas kesesuaian lahan marjinal (S3) cukup luas. Adanya daerah basis yang terdapat dilokasi sesuai marjinal (S3) dikarenakan tanaman deres merupakan budaya turun temurun. Kelapa deres dipanen dalam bentuk nira sebagai bahan pembuatan gula kelapa. Banyaknya wilayah sebagai basis komoditas kelapa deres tetapi mempunyai pangsa pertumbuhan negatif disebabkan banyaknya tanaman yang sudah tua yang sudah tidak produktif dan ditebang untuk digunakan sebagai kayu bangunan.

Wilayah pengembangan tanaman kelapa deres hampir sama dengan kelapa dalam dikarenakan jenis kelapa merupakan jenis kelapa yang sama dan merupakan wilayah fungsional dataran rendah yang menjadi satu kesatuan yaitu di Kabupaten Banjarnegara bagian selatan melintang dari barat sampai timur.

\section{Kopi Arabika}

Kopi arabika dipilih menjadi komoditas unggulan berdasarkan pendapat stakeholder perkebunan (metode Delphi) dikarenakan komoditas tersebut mempunyai tingkat permintaan pasar tinggi (peluang pasar bagus), didukung oleh pemerintah dan atau lembaga lain dalam pengembangan komoditas baik budidaya, pasca panen dan pasar dan tersedianya dukungan teknologi dalam budidaya dan penanganan pasca panen.

Kopi arabika dengan luas panen $218 \mathrm{Ha}$ dan produktivitas $670 \mathrm{~kg} / \mathrm{ha} / \mathrm{th}$ (equivalen kopi wose) merupakan wilayah basis di Jawa Tengah, walaupun didominasi oleh Kabupaten Temanggung, Wonosobo dan Pemalang. Dengan luas panen masing-masing $1.048 \mathrm{Ha}, 609 \mathrm{Ha}$ dan $380 \mathrm{Ha}$. Produktivitas kopi arabika di Kabupaten Banjarnegara termasuk cukup bagus karena di atas rata-rata Jawa Tengah sebesar $573 \mathrm{~kg} / \mathrm{ha} / \mathrm{th}$, walaupun masih jauh dengan Kabupaten Temanggung sebesar $946 \mathrm{~kg} / \mathrm{ha} / \mathrm{th}$.

Dilihat besarnya nilai LQ, komoditas kopi arabika memiliki sebaran perwilayahan di Kecamatan Pejawaran, Kalibening, Pandanarum, Pagentan, Wanayasa, dan Karangkobar. Atas dasar tingkat kesesuaian lahan maka daerah yang paling potensial untuk pengembangan tanaman kopi arabika adalah di Kecamatan Pejawaran dan Pagentan. Luas tanaman kopi arabika tahun 2012 adalah 549,62 Ha sementara kesesuaian lahan potensial untuk kelas S2 (cukup sesuai) 617,64 Ha dan kelas S3 (Sesuai Marjinal) 53.634,48 Ha sehingga untuk pengembangan lebih lanjut terdapat hambatan yang cukup besar.

Berdasarkan analisis gabungan bahwa kecamatan yang paling potensial untuk pengembangan tanaman kopi arabika adalah Kecamatan Pejawaran dan Pagentan. Kecamatan Pandanarum dan Wanayasa juga mempunyai potensi dikarenakan merupakan daerah basis, pertumbuhan pangsa wilayah yang positif walaupun lahanya merupakan lahan sesuai marjinal (S3). Hal ini menunjukan bahwa petani masih mampu mengatasi hambatan yang terjadi dalam proses budidaya. Arahan pengembangan kopi arabika adalah 
wilayah yang memiliki daya saing yaitu kecamatan Pejawaran, Pagentan dan Wanayasa yang merupakan dataran tinggi.

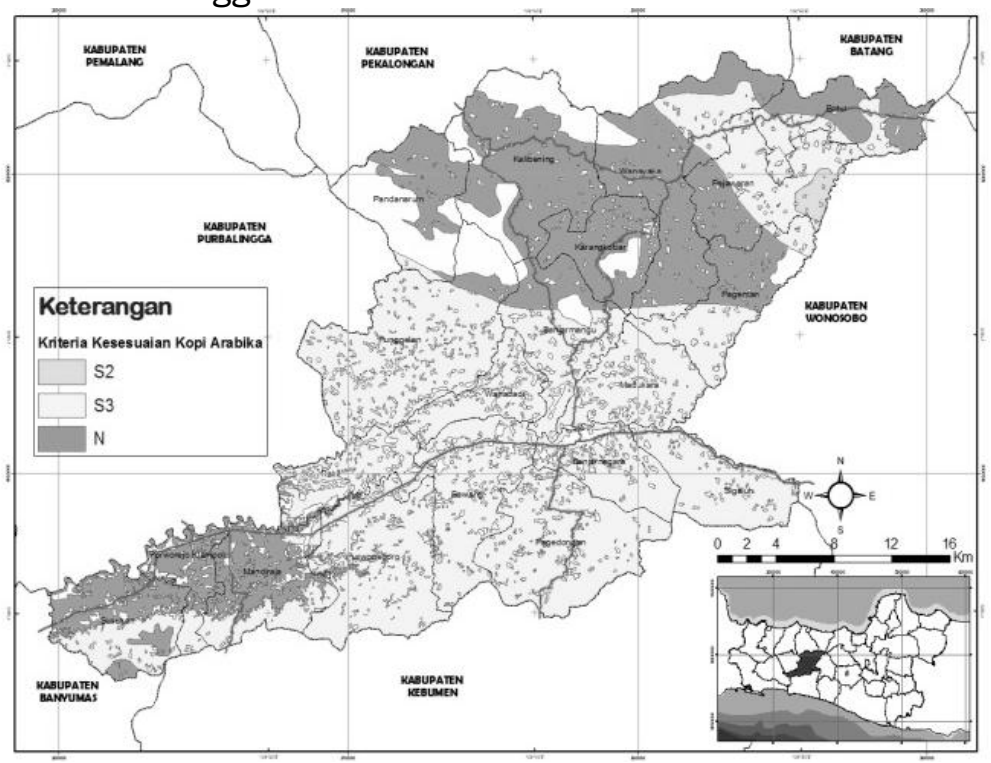

\section{Gambar 2. Peta Kesesuaian Lahan Tanaman Kopi Arabika di Kabupaten Banjarnegara}

\section{Kopi Robusta}

Kopi robusta menjadi komodias unggulan oleh pemegang kebijakan dikarenakan komoditas tersebut cocok diusahakan di daerah tersebut (agroklimat sesuai) dan tersedianya dukungan teknologi dalam budidaya dan penanganan pasca panen. Luas kesesuian lahan 62.169,96 Ha dengan luas eksisting pada tahun 2012 seluas 1.859,79 Ha, produksi 875,43 ton biji kering menjadikan tanaman ini sangat bisa dikembangkan lebih lanjut.

Kopi robusta merupakan komoditas non-basis di Kabupaten Banjarnegara jika dibandingkan dengan kabupaten lain di Jawa Tengah. Kopi robusta di Kabupaten Banjarnegara bukan merupakan wilayah basis di Jawa Tengah, dengan produktivitas di bawah rata-rata Jawa Tengah. Tetapi potensi kesesuaian lahan masih cukup luas untuk pengembangan tanaman kopi robusta. Dilihat dari urutan besarnya nilai LQ, kopi robusta memiliki sebaran perwilayahan di deretan utara yaitu Kecamatan Karangkobar, Kalibening, Banjarnegara, Pandanarum, Batur, Wanayasa, Pagentan, Wanadadi dan Punggelan.

Berdasarkan analisis gabungan wilayah kecamatan yang paling potensial untuk pengembangan tanaman kopi robusta adalah Kecamatan Banjarnegara, Wanadadi, Punggelan yang memiliki tingkat kesesuaian lahan yang luas dan merupakan daerah basis. Pada wilayah yang mempunyai tingkat kesesuaian lahan baik tetapi belum merupakan daerah basis dikarenakan tanaman kopi masih dijadikan sebagai tanaman penyela saja bukan sebagai tanaman utama sehingga dalam usaha tani kopi robusta juga kurang optimal. 


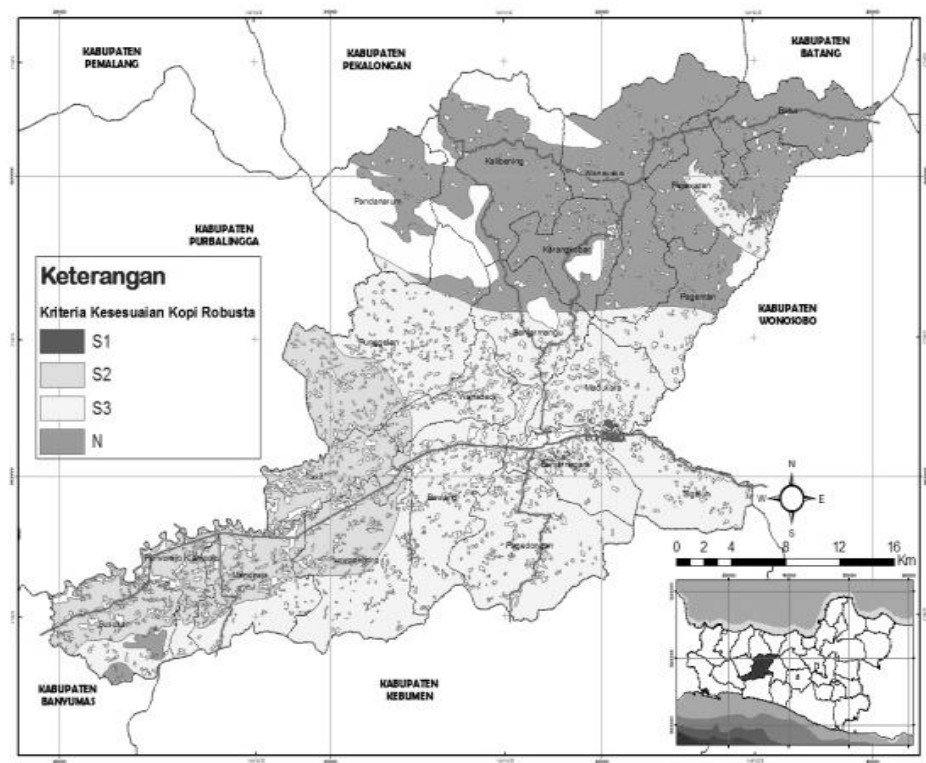

\section{Gambar 3. Peta Kesesuaian Lahan Tanaman Kopi Robusta di Kabupaten Banjarnegara}

Berdasarkan analisis kesesuaian lahan tanaman kopi robusta, wilayah kategori kelas Sangat Sesuai (S1) terdapat di kecamatan Susukan, Sigaluh, Madukara, Banjarnegara dan Banjarmangu.

\section{Teh}

Tanaman teh merupakan komoditas unggulan perkebunan kedua yang dipilih oleh para pemegang kebijakan pembangunan perkebunan di Kabupaten Banjarnegara. Kriteria yang paling banyak dipilih adalah masih tersedia potensi lahan untuk pengembangan komoditas tersebut dan didukung oleh pemerintah dan atau lembaga lain dalam pengembangan komoditas baik budidaya, pasca panen dan pasar. Hal ini sesuai dengan potensi kesesuaian lahan tanaman teh yang masih cukup luas yaitu seluas 5.996,91 Ha, sementara tanaman teh di Kabupaten Banjarnegara berdasarkan data tahun 2012 seluas 1.918,14 Ha dengan jumlah produksi $2.177,72$ ton daun basah yang diusahakan oleh 7.211 $\mathrm{KK}$.

Nilai LQ dari tahun 2011-2012, hasil rata-rata yang didapatkan memiliki nilai LQ luas panen paling besar adalah teh yang berarti komoditas tersebut merupakan komoditas basis jika dibandingkan dengan kabupaten lain di Jawa Tengah. Tanaman teh di Kabupaten Banjarnegara mempunyai luas tanaman menghasilkan terluas di Jawa Tengah yaitu seluas $1.433 \mathrm{Ha}$. Selanjutnya masing-masing Batang, Pekalongan dan Pemalang yaitu seluas $1.103 \mathrm{Ha}, 597 \mathrm{Ha}$ dan $561 \mathrm{Ha}$. Wilayah ini merupakan wilayah fungsional dari dataran tinggi Dieng sampai dengan lereng gunung Slamet yang merupakan wilayah dataran tinggi. Produktivitas teh di Kabupaten Banjarnegara sebesar $1.524 \mathrm{~kg} / \mathrm{ha}$ sama dengan produktivitas tanaman teh rata-rata Jawa Tengah $1.524 \mathrm{~kg} / \mathrm{ha}$. Hal ini dapat dikatakan bahwa tanaman teh di Kabupaten Banjarnegara cukup potensi dan memegang peranan penting di Jawa Tengah. 


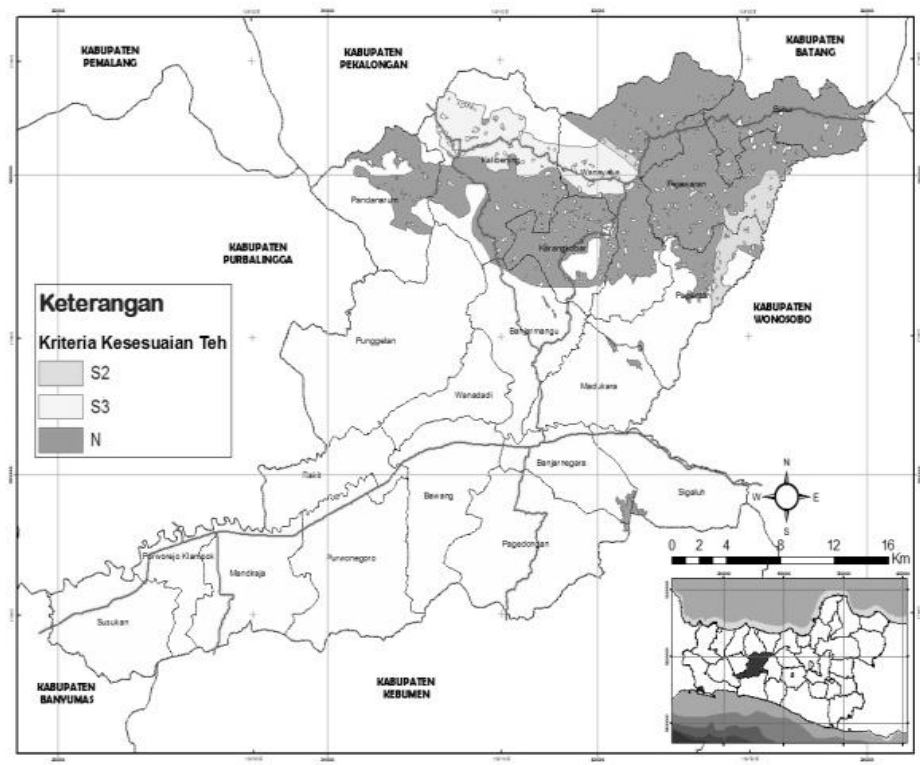

Gambar 4. Peta Kesesuaian Lahan Tanaman Teh di Kabupaten Banjarnegara

Wilayah basis teh di Kabupaten Banjarnegara berada di Kecamatan Wanayasa, Batur, Kalibening, Karangkobar, Pandanarum dan Pagentan. Melihat tingkat kelas kesesuaian lahan yang cukup sedikit pada kelas S2 dan S3 menjadikan tanaman teh merupakan tanaman spesifik dan hanya dapat tumbuh dengan baik pada daerah tertentu terutama pada daerah dengan suhu cukup dingin dengan ketinggian diatas $1.200 \mathrm{~m}$ diatas permukaan air laut. Untuk variabel yang bersifat permanen seperti ketinggian tempat dan kemiringan, petani, pihak swasta maupun pemerintah tidak bisa menanggulangi faktor penghambat tersebut. Hal ini dikarenakan banyak tanaman teh yang terdapat di lokasi yang masuk dalam kelas sesuai marjinal (S3).

Berdasarkan analisis kesesuaian lahan tanaman teh terdapat kelas cukup sesuai (S2) terdapat di kecamatan Pagentan, Pejawaran dan Wanayasa dan kelas sesuai marginal (S3) terdapat di Kecamatan Wanayasa, Pejawaran, dan Kalibening.

Perkebunan teh merupakan perkebunan yang sangat mendapat dukungan dari pihak swasta, sehingga faktor penghambat dapat diminimalkan untuk dapat meningkatkan produksi tanaman dengan baik.

\section{Karet}

Karet merupakan tanaman yang baru dikembangkan tetapi langsung mendapat perhatian dari masyarakat dan pemerintah. Kriteria tersedianya dukungan teknologi dalam budidaya dan penanganan pasca panen, didukung oleh pemerintah dan atau lembaga lain dalam pengembangan komoditas baik budidaya, pasca panen dan pasar dan masih tersedia potensi lahan untuk pengembangan komoditas tersebut mendapat perhatian dari pemegang kebijakan. Luas lahan karet di Kabupaten Banjarnegara 78,2 Ha dengan luas lahan sesuai (S) 59.084,9 Ha sehingga potensi perluasan areal masih sangat memungkinkan. 


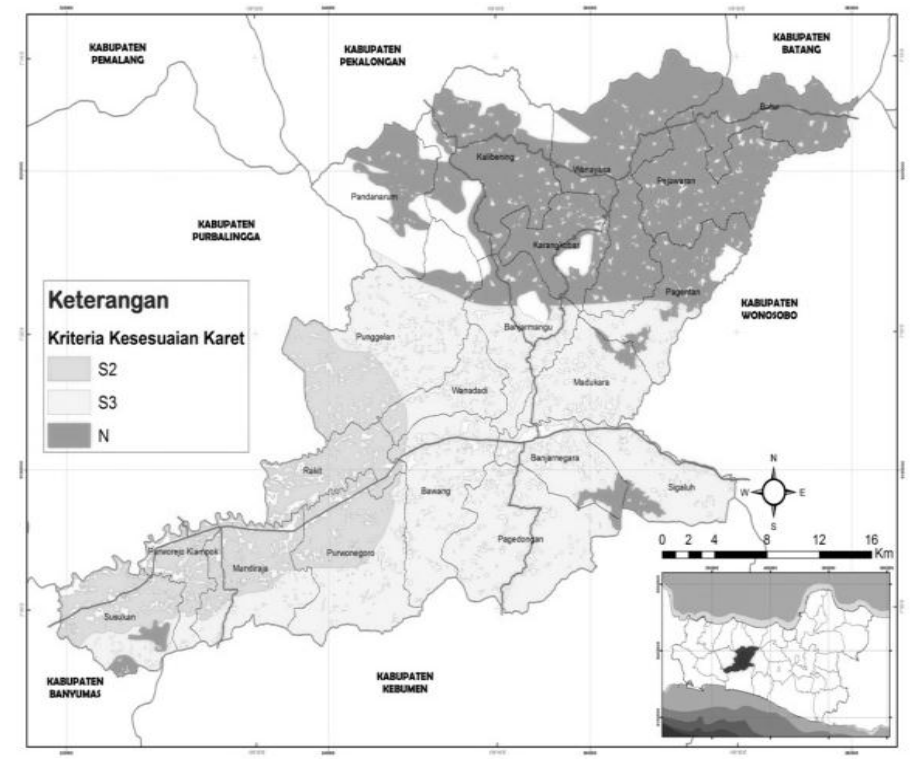

Gambar 5. Peta Kesesuaian Lahan Tanaman Karet di Kabupaten Banjarnegara

Berdasarkan analisis gabungan diatas dapat diterangkan bahwa kecamatan yang paling potensial untuk pengembangan tanaman karet adalah Kecamatan Punggelan, Purwonegoro, Susukan, Rakit, Mandiraja, Purworejo Klampok dan Wanadadi, dimana lokasi tersebut memiliki tingkat kesesuaian lahan sangat sesuai (S1) untuk komoditas yang cukup luas. Berdasarkan data dari Dinas Kehutanan dan Perkebunan tahun 2012, tanaman karet hanya terdapat di Kecamatan Pagedongan, walaupun di daerah tersebut hanya memiliki kesesuaian lahan S2 (cukup sesuai).

Melihat tingkat kelas kesesuaian lahan yang cukup luas pada kelas S2 dan S3 menjadikan tanaman karet mempunyai potensi untuk dapat dikembangkan terutama untuk daerah di bawah ketinggian $700 \mathrm{~m}$ diatas permukaan laut. Saat ini luas tanaman karet masih sangat sedikit yaitu hanya seluas $78 \mathrm{Ha}$, sehingga potensi pengembangan karet masih sangat baik. Masyarakat petani bersama pemerintah sedang menggalakan program perluasan areal karet melalui pemberian bibit unggul bersertifikat.

\section{Tebu}

Berdasarkan analisis gabungan diatas dapat diterangkan bahwa kecamatan yang paling potensial untuk pengembangan tanaman tebu adalah Kecamatan Bawang yang mempunyai kelas sangat sesuai (S1) dan merupakan daerah basis. Tingkat kesesuain lahan untuk tanaman tebu di Kabupaten Banjarnegara sangat luas yang terletak di Kecamatan Purwonegoro, Susukan, Mandiraja, Rakit dan Wanadadi. Wilayah pengembangan tanaman tebu terdapat didataran rendah-menengah dan merupakan wilayah fungsional di Kabupaten Banjarnegara selatan dan tengah yang membujur dari barat sampai timur. Tebu merupakan tanaman yang baru dikembangkan di Kabupaten banjarnegara dalam rangka mendukung program pemerintah dalam swasembada gula. Kriteria masih tersedia potensi lahan untuk pengembangan komoditas tersebut, komoditas cocok diusahakan di daerah tersebut (agroklimat sesuai) dan tersedianya dukungan teknologi dalam budidaya dan penanganan pasca panen menjadikan tebu menjadi salah satu komoditas unggulan. Tingkat kesesuaian lahan seluas 53.050,05 Ha, dimana 18.155,51 Ha masuk kategori sangat sesuai (S1) menjadikan tebu sangat potensial untuk dikembangkan di Kabupaten Banjarnegara. Kelas Sangat Sesuai (S1) dan Cukup Sesuai (S2) terdapat hampir di seluruh 
kecamatan. Kecamatan yang mempunyai potensi paling sesuai dengan luasan yang besar untuk tanaman tebu adalah Kecamatan Bawang, Mandiraja, Purwonegoro, Susukan dan Rakit. Di Kecamatan Punggelan juga mempunyai potensi pengembangan yang cukup luas walaupun terdapat faktor penghambat.

Dukungan teknologi budidaya dari pemerintah juga sangat besar, yaitu antara lain dengan pemberian mesin pengolah tanah, alat panen dan kerjasama dengan pabrik gula. Kelembagaan tebu di Kabupaten Banjarnegara juga cukup bagus antara lain dengan didirikanya KPTR (Koperasi Petani Tebu Rakyat) Gendhis Abadi.

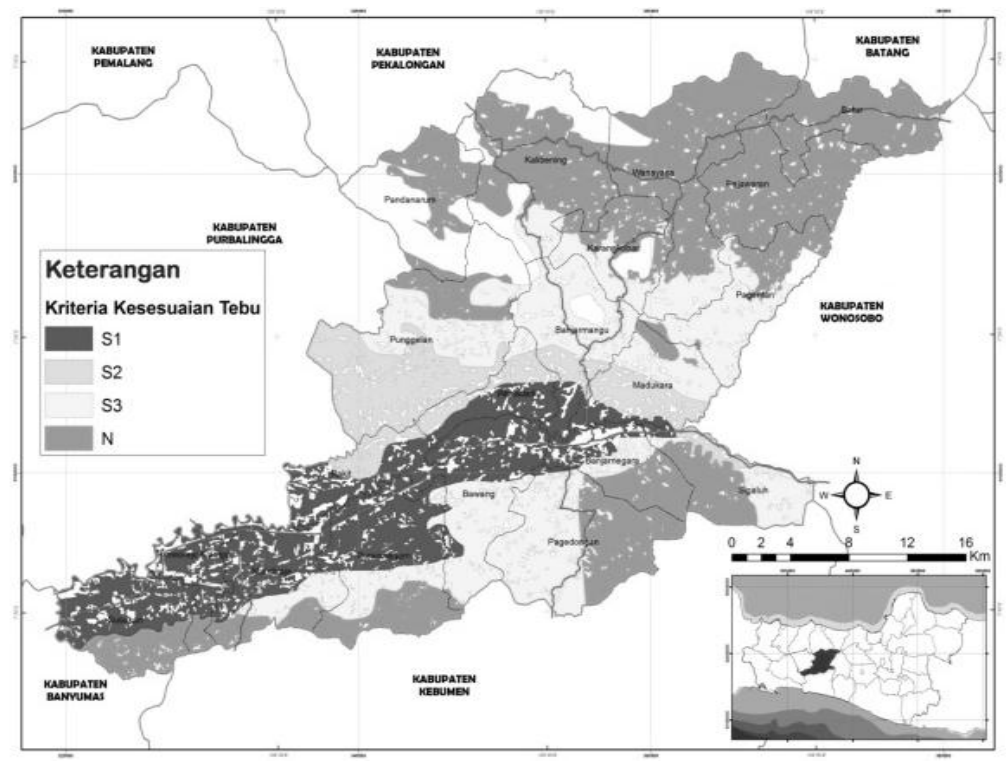

\section{Gambar 6. Peta Kesesuaian Lahan Tanaman Tebu di Kabupaten Banjarnegara}

Melihat tingkat kelas kesesuaian lahan yang cukup luas pada kelas S1 dan S2 menjadikan tanaman tebu mempunyai potensi untuk dapat dikembangkan terutama untuk daerah di bawah ketinggian $800 \mathrm{~m}$ diatas permukaan laut. Walaupun pada kelas lahan S3 cukup luas tetapi karena faktor penghambatnya merupakan faktor penghambat permanen yaitu ketinggian tempat sehingga agak sulit diatasi oleh petani, swasta maupun pemerintah.

Dalam pengembangan wilayah berbasis komoditas perkebunan unggulan, masingmasing kecamatan mempunyai potensi pengembangan yang berbeda-beda. Hal ini disebabkan oleh karakteristik fisik lahan yang sangat bervariasi, syarat tumbuh tanaman yang berbeda-beda, regulasi pemanfaatan lahan, tingkat kesesuaian lahan, kebiasaan petani dalam budidaya tanaman dan kebijakan pemerintah dalam melakukan program pembangunan.

Tabel 1. Hasil Analisis Gabungan Antara Kesesuaian Lahan Komoditas, Location Quotient, dan Shift- Share

\begin{tabular}{c|c|c|c|c|c|c|c|c}
\hline \multirow{2}{*}{ No. } & \multirow{2}{*}{ Kecamatan } & \multicolumn{7}{|c}{ Arahan Pengembangan Komoditas } \\
\cline { 3 - 8 } & $\begin{array}{c}\text { Kelapa } \\
\text { Deres }\end{array}$ & $\begin{array}{c}\text { Kelapa } \\
\text { Dalam }\end{array}$ & $\begin{array}{c}\text { Kopi } \\
\text { Arabika }\end{array}$ & $\begin{array}{c}\text { Kopi } \\
\text { Robusta }\end{array}$ & T e h & Karet & Tebu \\
\hline 1. & Banjarmangu & $\begin{array}{c}\text { kurang } \\
\text { potensi }\end{array}$ & potensi & $\begin{array}{c}\text { kurang } \\
\text { potensi }\end{array}$ & $\begin{array}{c}\text { cukup } \\
\text { potensi }\end{array}$ & $\begin{array}{c}\text { tidak } \\
\text { potensi }\end{array}$ & $\begin{array}{c}\text { kurang } \\
\text { potensi }\end{array}$ & potensi \\
\hline 2. & Banjarnegara & $\begin{array}{c}\text { kurang } \\
\text { potensi }\end{array}$ & potensi & $\begin{array}{c}\text { kurang } \\
\text { potensi }\end{array}$ & potensi & $\begin{array}{c}\text { tidak } \\
\text { potensi }\end{array}$ & $\begin{array}{c}\text { kurang } \\
\text { potensi }\end{array}$ & potensi \\
\hline
\end{tabular}




\begin{tabular}{|c|c|c|c|c|c|c|c|c|}
\hline \multirow[b]{2}{*}{ No. } & \multirow[b]{2}{*}{ Kecamatan } & \multicolumn{7}{|c|}{ Arahan Pengembangan Komoditas } \\
\hline & & $\begin{array}{c}\text { Kelapa } \\
\text { Deres }\end{array}$ & $\begin{array}{l}\text { Kelapa } \\
\text { Dalam }\end{array}$ & $\begin{array}{c}\text { Kopi } \\
\text { Arabika }\end{array}$ & $\begin{array}{c}\text { Kopi } \\
\text { Robusta }\end{array}$ & Te h & Karet & Tebu \\
\hline 3. & Batur & $\begin{array}{c}\text { tidak } \\
\text { potensi }\end{array}$ & $\begin{array}{l}\text { tidak } \\
\text { potensi }\end{array}$ & $\begin{array}{l}\text { kurang } \\
\text { potensi }\end{array}$ & $\begin{array}{c}\text { tidak } \\
\text { potensi }\end{array}$ & $\begin{array}{c}\text { tidak } \\
\text { potensi }\end{array}$ & $\begin{array}{c}\text { tidak } \\
\text { potensi }\end{array}$ & $\begin{array}{c}\text { tidak } \\
\text { potensi }\end{array}$ \\
\hline 4. & Bawang & potensi & $\begin{array}{l}\text { sangat } \\
\text { potensi }\end{array}$ & $\begin{array}{l}\text { tidak } \\
\text { potensi }\end{array}$ & $\begin{array}{l}\text { cukup } \\
\text { potensi }\end{array}$ & $\begin{array}{c}\text { tidak } \\
\text { potensi }\end{array}$ & $\begin{array}{l}\text { cukup } \\
\text { potensi }\end{array}$ & $\begin{array}{l}\text { sangat } \\
\text { potensi }\end{array}$ \\
\hline 5. & Kalibening & $\begin{array}{c}\text { tidak } \\
\text { potensi }\end{array}$ & $\begin{array}{c}\text { tidak } \\
\text { potensi }\end{array}$ & $\begin{array}{c}\text { tidak } \\
\text { potensi }\end{array}$ & $\begin{array}{c}\text { tidak } \\
\text { potensi }\end{array}$ & potensi & $\begin{array}{c}\text { tidak } \\
\text { potensi }\end{array}$ & $\begin{array}{l}\text { kurang } \\
\text { potensi }\end{array}$ \\
\hline 6. & Karangkobar & $\begin{array}{c}\text { tidak } \\
\text { potensi }\end{array}$ & $\begin{array}{c}\text { tidak } \\
\text { potensi }\end{array}$ & $\begin{array}{l}\text { kurang } \\
\text { potensi }\end{array}$ & potensi & $\begin{array}{c}\text { tidak } \\
\text { potensi }\end{array}$ & $\begin{array}{c}\text { tidak } \\
\text { potensi }\end{array}$ & $\begin{array}{l}\text { kurang } \\
\text { potensi }\end{array}$ \\
\hline 7. & Madukara & $\begin{array}{l}\text { kurang } \\
\text { potensi }\end{array}$ & potensi & $\begin{array}{l}\text { kurang } \\
\text { potensi }\end{array}$ & $\begin{array}{l}\text { cukup } \\
\text { potensi }\end{array}$ & $\begin{array}{c}\text { tidak } \\
\text { potensi }\end{array}$ & $\begin{array}{l}\text { kurang } \\
\text { potensi }\end{array}$ & potensi \\
\hline 8. & Mandiraja & $\begin{array}{l}\text { sangat } \\
\text { potensi }\end{array}$ & potensi & $\begin{array}{l}\text { kurang } \\
\text { potensi }\end{array}$ & $\begin{array}{l}\text { cukup } \\
\text { potensi }\end{array}$ & $\begin{array}{c}\text { tidak } \\
\text { potensi }\end{array}$ & $\begin{array}{l}\text { cukup } \\
\text { potensi }\end{array}$ & potensi \\
\hline 9. & Pagedongan & $\begin{array}{l}\text { cukup } \\
\text { potensi }\end{array}$ & potensi & $\begin{array}{l}\text { kurang } \\
\text { potensi }\end{array}$ & $\begin{array}{l}\text { cukup } \\
\text { potensi }\end{array}$ & $\begin{array}{c}\text { tidak } \\
\text { potensi }\end{array}$ & $\begin{array}{l}\text { kurang } \\
\text { potensi }\end{array}$ & potensi \\
\hline 10. & Pagentan & $\begin{array}{l}\text { kurang } \\
\text { potensi }\end{array}$ & $\begin{array}{l}\text { kurang } \\
\text { potensi }\end{array}$ & potensi & $\begin{array}{l}\text { cukup } \\
\text { potensi }\end{array}$ & $\begin{array}{l}\text { sangat } \\
\text { potensi }\end{array}$ & $\begin{array}{l}\text { kurang } \\
\text { potensi }\end{array}$ & $\begin{array}{l}\text { kurang } \\
\text { potensi }\end{array}$ \\
\hline 11. & Pandanarum & $\begin{array}{l}\text { kurang } \\
\text { potensi }\end{array}$ & $\begin{array}{l}\text { kurang } \\
\text { potensi }\end{array}$ & $\begin{array}{l}\text { cukup } \\
\text { potensi }\end{array}$ & $\begin{array}{l}\text { cukup } \\
\text { potensi }\end{array}$ & $\begin{array}{c}\text { tidak } \\
\text { potensi }\end{array}$ & $\begin{array}{l}\text { kurang } \\
\text { potensi }\end{array}$ & $\begin{array}{c}\text { tidak } \\
\text { potensi }\end{array}$ \\
\hline 12. & Pejawaran & $\begin{array}{l}\text { kurang } \\
\text { potensi }\end{array}$ & $\begin{array}{l}\text { kurang } \\
\text { potensi }\end{array}$ & $\begin{array}{l}\text { sangat } \\
\text { potensi }\end{array}$ & $\begin{array}{l}\text { cukup } \\
\text { potensi }\end{array}$ & potensi & $\begin{array}{c}\text { tidak } \\
\text { potensi }\end{array}$ & $\begin{array}{c}\text { tidak } \\
\text { potensi }\end{array}$ \\
\hline 13. & Punggelan & $\begin{array}{l}\text { cukup } \\
\text { potensi }\end{array}$ & potensi & $\begin{array}{l}\text { kurang } \\
\text { potensi }\end{array}$ & potensi & $\begin{array}{c}\text { tidak } \\
\text { potensi }\end{array}$ & $\begin{array}{l}\text { cukup } \\
\text { potensi }\end{array}$ & potensi \\
\hline 14. & Purwonegoro & $\begin{array}{l}\text { cukup } \\
\text { potensi }\end{array}$ & $\begin{array}{l}\text { sangat } \\
\text { potensi }\end{array}$ & $\begin{array}{l}\text { kurang } \\
\text { potensi }\end{array}$ & $\begin{array}{l}\text { cukup } \\
\text { potensi }\end{array}$ & $\begin{array}{c}\text { tidak } \\
\text { potensi }\end{array}$ & $\begin{array}{l}\text { cukup } \\
\text { potensi }\end{array}$ & potensi \\
\hline 15. & Pwj Klampok & $\begin{array}{l}\text { cukup } \\
\text { potensi }\end{array}$ & potensi & $\begin{array}{l}\text { kurang } \\
\text { potensi }\end{array}$ & $\begin{array}{l}\text { cukup } \\
\text { potensi }\end{array}$ & $\begin{array}{c}\text { tidak } \\
\text { potensi }\end{array}$ & $\begin{array}{l}\text { cukup } \\
\text { potensi }\end{array}$ & potensi \\
\hline 16. & Rakit & potensi & $\begin{array}{l}\text { sangat } \\
\text { potensi }\end{array}$ & $\begin{array}{l}\text { kurang } \\
\text { potensi }\end{array}$ & $\begin{array}{l}\text { cukup } \\
\text { potensi }\end{array}$ & $\begin{array}{c}\text { tidak } \\
\text { potensi }\end{array}$ & $\begin{array}{l}\text { cukup } \\
\text { potensi }\end{array}$ & potensi \\
\hline 17. & Sigaluh & $\begin{array}{l}\text { cukup } \\
\text { potensi }\end{array}$ & potensi & $\begin{array}{l}\text { kurang } \\
\text { potensi }\end{array}$ & $\begin{array}{l}\text { cukup } \\
\text { potensi }\end{array}$ & $\begin{array}{c}\text { tidak } \\
\text { potensi }\end{array}$ & $\begin{array}{l}\text { kurang } \\
\text { potensi }\end{array}$ & potensi \\
\hline 18. & Susukan & $\begin{array}{l}\text { sangat } \\
\text { potensi }\end{array}$ & $\begin{array}{l}\text { sangat } \\
\text { potensi }\end{array}$ & $\begin{array}{l}\text { kurang } \\
\text { potensi }\end{array}$ & $\begin{array}{l}\text { cukup } \\
\text { potensi }\end{array}$ & $\begin{array}{c}\text { tidak } \\
\text { potensi }\end{array}$ & $\begin{array}{l}\text { cukup } \\
\text { potensi }\end{array}$ & potensi \\
\hline 19. & Wanadadi & $\begin{array}{l}\text { cukup } \\
\text { potensi }\end{array}$ & $\begin{array}{l}\text { sangat } \\
\text { potensi }\end{array}$ & $\begin{array}{l}\text { kurang } \\
\text { potensi }\end{array}$ & $\begin{array}{l}\text { cukup } \\
\text { potensi }\end{array}$ & $\begin{array}{c}\text { tidak } \\
\text { potensi }\end{array}$ & $\begin{array}{l}\text { cukup } \\
\text { potensi }\end{array}$ & potensi \\
\hline 20. & Wanayasa & $\begin{array}{l}\text { kurang } \\
\text { potensi }\end{array}$ & potensi & $\begin{array}{l}\text { cukup } \\
\text { potensi }\end{array}$ & $\begin{array}{l}\text { cukup } \\
\text { potensi }\end{array}$ & $\begin{array}{l}\text { sangat } \\
\text { potensi }\end{array}$ & $\begin{array}{l}\text { kurang } \\
\text { potensi }\end{array}$ & $\begin{array}{l}\text { kurang } \\
\text { potensi }\end{array}$ \\
\hline
\end{tabular}

\section{Kesimpulan}

Berdasarkan dari hasil penelitian, analisis dan pembahasan yang telah dilakukan dapat ditarik beberapa kesimpulan sebagai berikut :

1. Kriteria utama komoditas perkebunan unggulan di Kabupaten Banjarnegara adalah komoditas tersebut cocok diusahakan di wilayah tersebut (agroklimat sesuai), masih tersedia potensi lahan untuk pengembangan dan komoditas yang mempunyai harga jual produksi yang baik dan dapat memberikan keuntungan (nilai ekonomi) tinggi.

2. Komoditas unggulan prioritas berdasarkan kriteria komoditas unggulan dan potensi komoditas unggulan adalah berturut-turut kelapa deres, teh, kopi arabika, kopi robusta, kelapa dalam, karet dan tebu.

3. Komoditas perkebunan yang mempunyai keunggulan komparatif di Jawa Tengah adalah teh, kelapa deres, kelapa dalam dan kopi arabika. 
4. Tingkat kesesuaian lahan dengan kategori kesesuaian lahan Sesuai (S) di Kabupaten Banjarnegara mempunyai potensi yang cukup luas, sehingga pengembangan wilayah kecamatan berbasis komoditas perkebunan dapat dikembangkan lebih lanjut.

5. Pertumbuhan tanaman perkebunan unggulan di Kabupaten Banjarnegara cukup baik dan wilayah kecamatan yang mempunyai pertumbuhan pangsa wilayah komoditas perkebunan unggulan paling baik adalah Kecamatan Pagedongan.

6. Berdasarkan analisis gabungan antara LQ, SS dan kesesuaian lahan potensial, strategi perwilayahan komoditas perkebunan unggulan di Kabupaten Banjarnegara mempunyai perwilayahan pengembangan sebagai berikut :

a. Kelapa deres di Kecamatan Bawang, Rakit dan Susukan

b. Teh di Kecamatan Kalibening, Pagentan dan Pejawaran

c. Kopi arabika di Kecamatan Pagentan dan Pejawaran

d. Kopi robusta di Kecamatan Banjarnegara, Karangkobar dan Punggelan

e. Kelapa dalam di Kecamatan Banjarmangu, Banjarnegara, Madukara, Mandiraja, Pagedongan, Punggelan, Purwonegoro, Purworejo Klampok, Rakit dan Susukan.

f. Karet di Kecamatan Bawang, Mandiraja, Punggelan, Purwonegoro, Purworejo Klampok, Rakit, Susukan dan Wanadadi

g. Tebu di Kecamatan Banjarmangu, Banjarnegara, Madukara, Mandiraja, Punggelan, Purwonegoro, Purworejo Klampok, Rakit, Suuskan dan Wanadadi.

\section{Daftar Pustaka}

Baja, S. 2012. Perencanaan Tata Guna Lahan Dalam Pengembangan Wilayah, Pendekatan Spasial dan Aplikasinya., Yogyakarta: Andi Offset.

Banjarnegara Dalam Angka Tahun 2012. Badan Pusat Statistik Kabupaten Banjarnegara 2012.

Hendayana, Rachmat. 2002. Aplikasi Metode Location Quotient (LQ) dalam Penentuan Komoditas Unggulan. Bogor: Balai Pengkajian dan Pengembangan Teknologi Pertanian

Herdhiansyah, Dian dkk. Strategi Pengembangan Potensi Wilayah Agroindustri Perkebunan Unggulan. Jurnal Teknik Industri Vol. 13 No. 2, Agustus 2012; 201-209.

Produk Domestik Regional Bruto Kabupaten Banjarnegara 2011. 2012. Bappeda dan BPS Kabupaten Banjarnegara.

Rencana Pembangunan Jangka Menengah Daerah Kabupaten Banjarnegara Tahun 2011 - 2016. 2012. Bappeda Kabupaten Banjarnegara.

Rencana Tata Ruang Wilayah Kabupaten Banjarnegara 2011 -2031. 2011. Bappeda Kabupaten Banjarnegara.

Rustiadi E, Sunsun Saefulhakim dan Dyah R. Panuju. 2011. Perencanaan dan Pengembangan Wilayah. Jakarta: Yayasan Obor Indonesia.

Suparmoko. 2001. Ekonomi Publik, Untuk Keuangan dan Pembangunan Daerah, Edisi Pertama. Yogyakarta: Penerbit Andi

Surat Keputusan Menteri Pertanian Nomor 837/Kpts/Um/11/1980 tentang Kriteria Dan Tata Cara Penetapan Hutan Lindung.

Surat Keputusan Menteri Pertanian Nomor 638/Kpts/Um/8/1981 tentang Kriteria Dan Tata Cara Penetapan Hutan Produksi.

Tarigan, Robinson. 2004. Perencanaan Pembangunan Wilayah. Jakarta : PT Bumi aksara.

Tarigan Robinson. 2005. Ekonomi Regional Teori dan Aplikasinya. Edisi Revisi. Jakarta: PT Bmi Aksara.

Undang-Undang Nomor 18 Tahun 2004 Tentang Perkebunan. 
156 Komoditas Perkebunan Unggulan yang Berbasis Pada Pengembangan Wilayah Kecamatan...

JURNAL WILAYAH DAN LINGKUNGAN, 2 (2), 143-156 